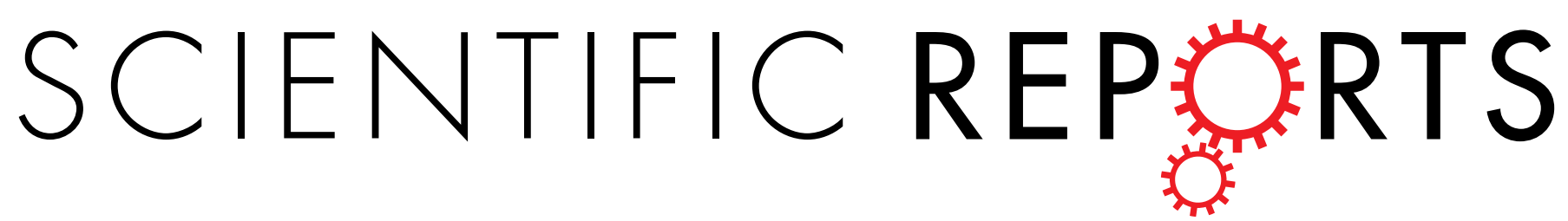

\title{
OPEN Erratum: Protein Sequence Comparison Based on Physicochemical Properties and the Position-Feature Energy Matrix
}

LuluYu, Yusen Zhang, Ivan Gutman, Yongtang Shi \& Matthias Dehmer

Scientific Reports 7:46237; doi: 10.1038/srep46237; published online 10 April 2017; updated on 04 May 2017

In the original version of this Article, Yusen Zhang was incorrectly affiliated with 'Faculty of Science, University of Kragujevac, P. O. Box 60, 34000 Kragujevac, Serbia'. The correct affiliation is listed below.

School of Mathematics and Statistics, Shandong University at Weihai, Weihai 264209, China.

This error has now been corrected in the PDF and HTML versions of the Article.

(c) (i) This work is licensed under a Creative Commons Attribution 4.0 International License. The images or other third party material in this article are included in the article's Creative Commons license, unless indicated otherwise in the credit line; if the material is not included under the Creative Commons license, users will need to obtain permission from the license holder to reproduce the material. To view a copy of this license, visit http://creativecommons.org/licenses/by/4.0/

(C) The Author(s) 2017 